\author{
Mikołaj KUZINOVSKI ${ }^{1}$ \\ Mite TOMOV ${ }^{2}$ \\ Piotr CICHOSZ \\ Pawet KAROLCZAK ${ }^{4}$ \\ Maciej KOWALSKI ${ }^{5}$ \\ Marek KOLODZIEJ ${ }^{6}$ \\ Hubert SKOWRONEK ${ }^{7}$ \\ Kamil WASZCZUK
}

\title{
ANALIZA ROZKŁADU SIŁ DZIAŁAJĄCYCH NA OSTRZE FAZOWNIKA SPRĘŻYSTEGO
}

\begin{abstract}
W pracy dokonano analizy rozkładu sił działających na ostrze skrawające w samoczynnych fazownikach. W rozważaniach wzięto pod uwagę fazowniki z różnymi rodzajami sprężyn płaskich służących do napinania ostrza. Przedstawiono czynniki wpływające na charakterystyki podatnościowe sprężyn. Sprecyzowano wytyczne do doboru najkorzystniejszych wariantów sprężyn z punktu widzenia najkorzystniejszych warunków pracy fazowników. Zwrócono uwagę na zmiany sił, jakie działają na ostrze w różnych cyklach pracy fazownika. Wyznaczono wartości sił skrawania, jakie mogą wystąpić podczas kształtowania krawędzi przedmiotów. W analizach uwzględniano także działające siły odśrodkowe oraz zmianę sił od odkształceń sprężystych elementów napinających ostrze.
\end{abstract}

Słowa kluczowe: fazowanie krawędzi, skrawanie, fazowniki, projektowanie narzędzi

\section{Wprowadzenie}

Nowoczesne narzędzia skrawające pozwalają na usprawnienie procesu wytwarzania dzięki swojej zwiększonej trwałości, uniwersalności lub rozszerzonej funkcjonalności [1]. Zadaniem projektowanego fazownika samoczynnego jest wykonanie poprawnej fazy na wejściu i wyjściu z otworu. W konstrukcji przedstawianego narzędzia dużą rolę odgrywa bilans sił działających na jego ostrze

\footnotetext{
3 Autor do korespondencji/corresponding author: Piotr Cichosz, Politechnika Wrocławska, ul. Łukasiewicza 5, 50-371 Wrocław, tel.: 713202157, e-mail: piotr.cichosz@ pwr.edu.pl

1,2 Mikolaj Kuzinovski; Mite Tomov, University in Skopje, Republic of Macedonia, e-mail: mikolaj.kuzinovski@mf.edu.mk; mite.tomov@mf.edu.mk

4,5,6,7,8 Paweł Karolczak; Maciej Kowalski; Marek Kołodziej; Hubert Skowronek; Kamil Waszczuk, Politechnika Wrocławska, e-mail: pawel.karolczak@pwr.edu.pl; maciej.kowalski@pwr.wroc.pl; marek.kolodziej@pwr.edu.pl; hubert.skowronek@pwr.edu.pl; kamil.waszczuk@pwr.edu.pl
} 
skrawające. Ich poprawna analiza jest niezbędna w celu prawidłowego dobrania elementu sprężystego o najkorzystniejszych właściwościach. W tego typu rozwiązaniach można spotkać sprężyny śrubowe, talerzowe oraz piórowe. Rozwiązania te zostały szczegółowo opisane w pracach [1-3]. Przykładową konstrukcję fazownika ze sprężyną piórową zaprezentowano na rys. 1. Można ją zamocować bezpośrednio w korpusie narzędzia bądź poprzez kasetkę.

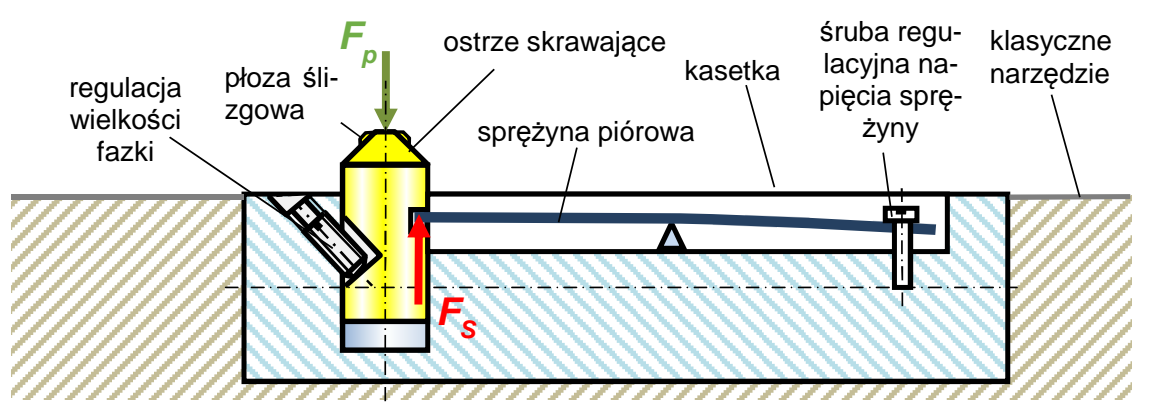

Rys. 1. Kasetka z fazownikiem samoczynnym ze sprężyną piórową, mocowana wewnątrz klasycznego narzędzia skrawającego

Fig. 1. Cassette of self-bevelling tool with flat spring, installed inside of the classic cutting tool

Konstrukcja fazownika zakłada odpowiednią geometrię ostrza skrawającego zintegrowanego z płozą ślizgową [2,4]. Ostrze wykonuje fazę na wejściu otworu, aż do chwili osiągnięcia jej żądanego wymiaru. Następnie wsuwa się do wnętrza kasetki dzięki płozie ślizgowej, która opiera się na wykonanej fazie i proces kszałtowania zostaje przerwany. Po wyjściu narzędzia $z$ dugiej strony otworu, a następnie jego wycofywaniu, w analogiczny sposób może być wykonywana faza na wylocie otworu. W opisywanym rozwiązaniu sprężyna piórowa wywiera siłę na ostrze skrawające, zapewniając jego docisk do powierzchni obrabianej. Siła docisku może być regulowana do wymaganej wartości za pomocą śruby. Wartość tej siły zależy w głównej mierze od rodzaju obrabianego materiału i wielkości fazy.

\section{Analiza rozkładu sił oddziałujących na ostrze skrawające fazownika}

Rozkład sił działających na segment z ostrzem skrawającym jest bardziej skomplikowany niż sugeruje to rys. 1 . W rzeczywistości segment ten stanowi swego rodzaju belkę o przekroju okrągłym, suwliwie osadzoną w otworze. Działają na nią siły, które w uproszczeniu można rozłożyć na składowe zgodnie z układem kartezjańskim. Największe trudności sprawia wyznaczenie sił tarcia. Co prawda siła tarcia, w pewnym uproszczeniu, zależy od siły normalnej i współ- 
czynnika tarcia, jednak wyznaczenie siły normalnej do powierzchni trących oraz miejsca jej przyłożenia nie jest łatwe (rys. 2).
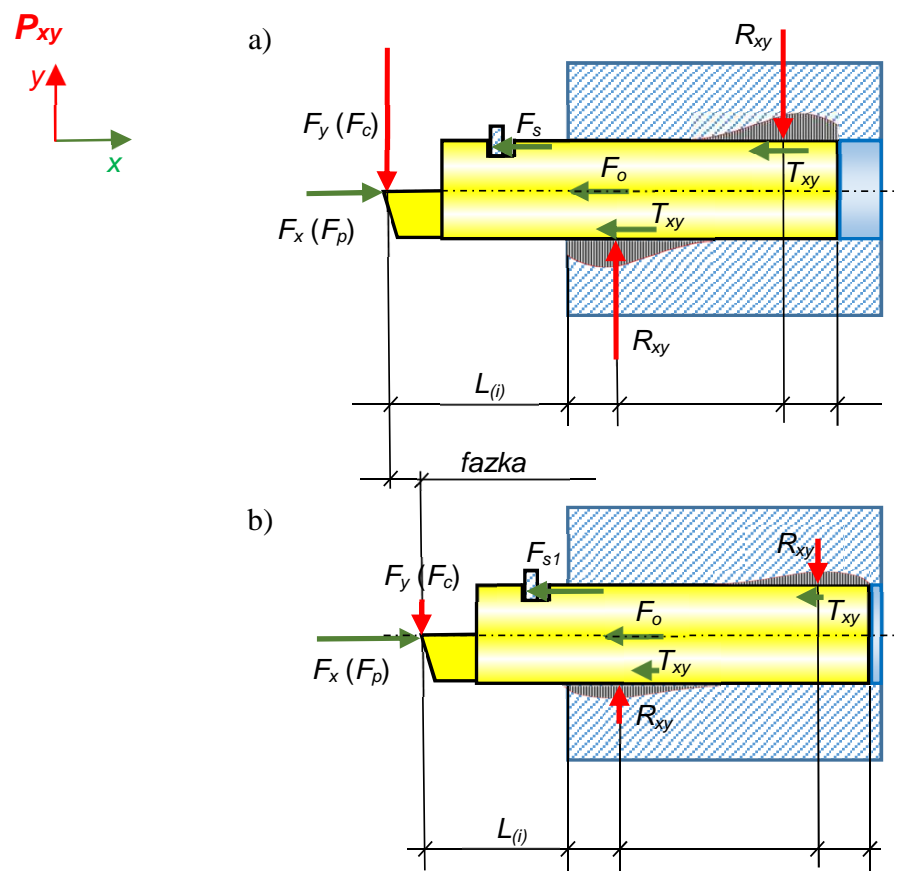

Rys. 2. Schematyczny rozkład sił działających w płaszczyźnie $P_{x-y}$ na segment z ostrzem: a) stan z końcowego stadium kształtowania fazy, b) stan po wycofaniu ostrza

Fig. 2. Schematic of distribution of forces acting on cutter in $P_{x-y}$ plane: a) state of the last stage of bevelling, b) state after cutter reverse move

Siły reakcji gniazda, np. w płaszczyźnie $P_{x y}$, nie są przyłożone punktowo, lecz $\mathrm{w}$ wyniku istnienia luzów oraz odkształceń sprężystych powierzchni stykowych mają pewien rozkład. Ponadto wartość sił reakcji, a co za tym idzie i sił tarcia, zależy od wysunięcia ostrza z gniazda. Im jest ono większe, tym przy tej samej sile skrawania $F_{c}$ moment utwierdzenia musi być większy. Na przedstawiony rozkład sił nakłada się jeszcze rozkład sił w płaszczyźnie $P_{x y}$. Wszystko to sprawia, że bilans sił wzdłuż osi $x$ ulega zmianom, trudnym do dokładnego określenia. Siły działające na segment z ostrzem skrawającym, w pewnym uproszczeniu, przedstawiono w chwili końcowego stadium kształtowania fazy na rys. 2a oraz po wycofaniu ostrza za pomocą płozy ślizgowej na rys. $2 \mathrm{~b}$. W celu określenia wymagań stawianych elementowi sprężystemu zastosowanemu w konstrukcji fazownika niezbędne jest przeanalizowanie w układzie przestrzennym rozkładu sił działających na ostrze, a zatem pośrednio także na samą sprężynę. Na rysun- 
ku 3 przedstawiono siły działające na przesuwny element z ostrzem skrawającym w końcowym stadium kształtowania fazy. Są to:

- siła skrawania $F_{c}$,

- siła odporowa $F_{p}$,

- siła posuwowa $F_{f}$,

- siła odśrodkowa $F_{o}$ (występuje, jeśli narzędzie wykonuje ruch obrotowy),

- siły tarcia $T_{x, y}, T_{x, z}$,

- siła oddziaływania sprężyny na ostrze $F_{s}$,

- siły reakcji korpusu na element z ostrzem $R_{x y}, R_{x z}$,

- siły na płozie ślizgowej $F_{f p(x, y)}, F_{f p(x, z)}$ (występują po zakończeniu wykonywania fazy i wycofaniu ostrza).

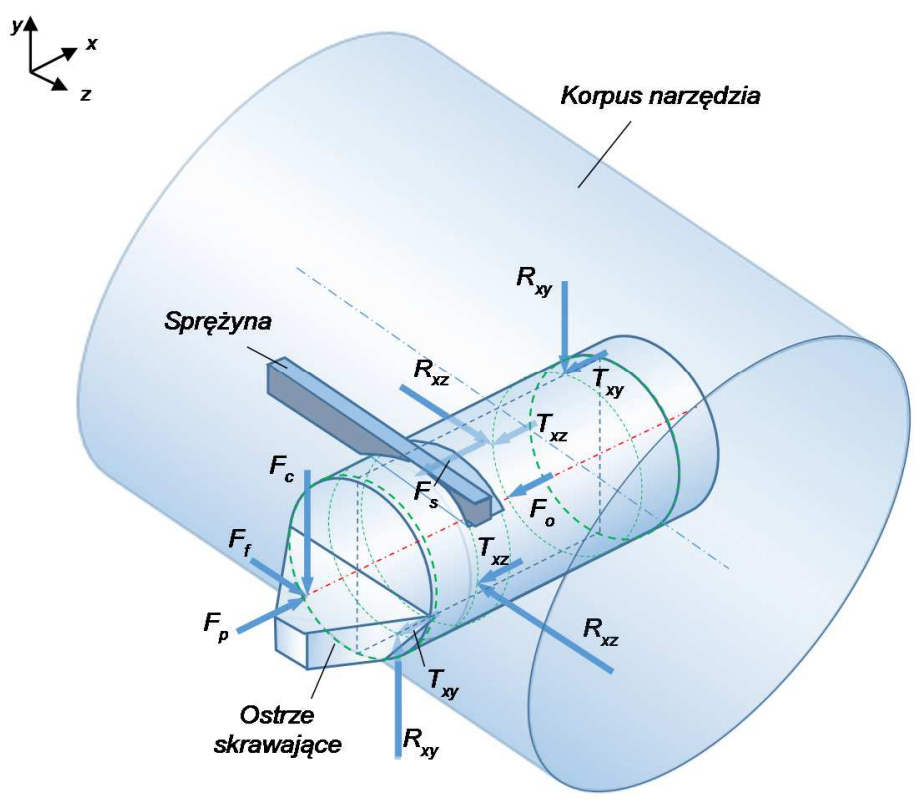

Rys. 3. Schemat rozkładu sił oddziałujących na ostrze skrawające fazownika

Fig. 3. Scheme of distribution of forces acting on the cutting edge of bevelling tool

Aby fazownik działał prawidłowo, siła sprężyny $F_{s}$ oddziałująca na ostrze musi być większa od sumy wszystkich sił działających podczas skrawania wzdłuż osi $x$ :

$$
F_{s}>F_{p}-F_{o}+\left(T_{x y}+T_{x z}\right)
$$


W chwili gdy płoza ślizgowa zacznie się opierać o wykonaną fazę, ostrze cofa się, znikają siły skrawania, a pojawiają się siły $F_{f p}$ oddziaływania fazy na płozę ślizgową [2]. Aby ostrze mogło się cofnąć, przerywając proces skrawania, siła $F_{s}, \mathrm{z}$ jaką oddziaływała do tej pory sprężyna na ostrze, musi być pokonana przez składową wypadkowej sił $F_{f p}$ działającej wzdłuż osi $x$ :

$$
F_{f p}>F_{s 1}+F_{o}+\left(T_{x y}+T_{x z}\right)
$$

Trzeba też pamiętać, że siła $F_{s}$ ulegnie zwiększeniu do $F_{s 1}$, ponieważ wzrośnie ugięcie tej sprężyny w porównaniu z tym, jakie było potrzebne, aby wywrzeć siłę $F_{s}$ przy maksymalnym wysunięciu ostrza. $\mathrm{Z}$ kolei siły tarcia $T_{x, y}, T_{x, z}$ zmniejszą się, bowiem - wobec zaniku sił skrawania $F_{c}$ i $F_{p}$ - zmniejszą się siły utwierdzenia ostrza $R_{x y}, R_{x z}$ w gnieździe kasetki.

\section{Dobór sprężyny piórowej}

Sprężyna piórowa do napinania ostrza skrawającego w fazowniku powinna zapewnić przemieszczenie go o $3 \mathrm{~mm}$, tak aby mogło się ono całkowicie schować w obrysie narzędzia po wykonaniu fazy. Wartość tego przemieszczenia wynika z zakładanej maksymalnej wielkości kształtowania fazy. Jednocześnie przy takiej wartości ugięcia sprężyny nie może zostać przekroczona jej maksymalna wytrzymałość na zginanie, aby nie nastąpiło jej odkształcenie plastyczne.

Przy długości sprężyny (wykonanej ze stali sprężynowej C67S) około $l=30 \mathrm{~mm}$, szerokości $b=7 \mathrm{~mm}$ i grubości $h=2 \mathrm{~mm}$ strzałka ugięcia wyniesie $1,5 \mathrm{~mm}$ dla siły obciążającej $500 \mathrm{~N}$. Jest to maksymalna wartość siły odpowiadająca wynikom prób skrawaniowych przeprowadzonych w zakładanych warunkach pracy fazowników. Wartość ugięcia jest więc dwukrotnie mniejsza od wymaganej. Ponadto wartość maksymalnego naprężenia

$$
\sigma_{\max }=\frac{M}{W}=\frac{6 \cdot F_{\max } \cdot l}{b \cdot h^{2}}
$$

Dla przytoczonych wcześniej danych $\sigma_{\max }=2389 \mathrm{MPa}$. Jest to wartość przekraczająca dopuszczalne naprężenia $\sigma_{d o p}=1500 \mathrm{MPa}$ dla stali sprężynowej C67S, z której wykonano sprężynę.

Kształt sprężyny można zoptymalizować, zmieniając pole jej przekroju poprzecznego wzdłuż długości sprężyny. Można na przykład zastosować sprężynę o zmiennej szerokości w kształcie trapezu lub o zmiennej grubości o kształcie parabolicznym. Taka zmienna geometria powoduje, w przybliżeniu równomierną, koncentrację naprężeń na całej jej długości i jednocześnie zmienia sztywność sprężyny, umożliwiając uzyskanie większej wartości strzałki ugięcia bez przekraczania granicy plastyczności materiału. Na rysunku 4 zostały przedstawione kształty sprężyn brane pod uwagę do zastosowania w fazowniku samoczynnym. 
a)

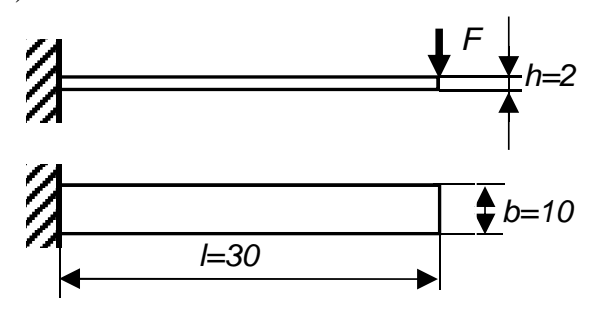

b)

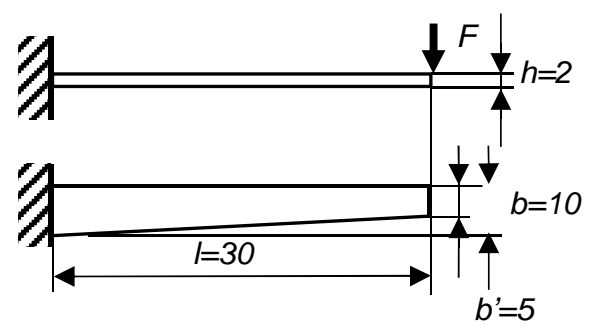

c)

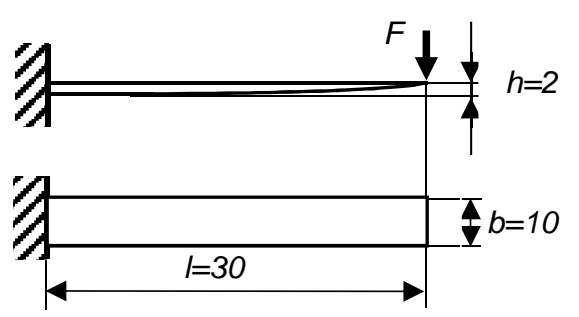

Rys. 4. Warianty sprężyn brane pod uwagę w konstrukcji fazownika: a) sprężyna płaska, b) sprężyna trapezowa, c) sprężyna paraboliczna

Fig. 4. Springs variants considered in the construction of the bevelling tool: a) flat spring, b) trapezoid spring, c) parabolic spring

Zależność strzałki ugięcia tych sprężyn od siły odporowej $F_{p}$ wywieranej na ostrze skrawające można wyznaczyć ze wzoru [5]:

$$
f=q \frac{l^{3}}{b h^{3}} \frac{F}{E}
$$

gdzie $q$-współczynnik zależny od kształtu sprężyny, wynoszący 4 dla sprężyny o stałym przekroju prostokątnym, 8 dla sprężyny o kształcie parabolicznym oraz $4 \cdot\left[3 /\left(2+\frac{b^{\prime}}{b}\right)\right]$ dla sprężyny o kształcie trapezu.

Zależności te zostały przedstawione na rys. 5 . Można zauważyć, że wszystkie charakterystyki są liniowe, lecz o różnym kącie pochylenia. Z punktu widzenia pracy fazownika najkorzystniejsza byłaby taka sprężyna, która podczas wycofywania ostrza powodowałaby możliwie małe przyrosty sił. Największą podatnością na odkształcenia wyróżnia się sprężyna o kształcie parabolicznym, jednak jest ona bardzo trudna do wykonania. $Z$ tego powodu $\mathrm{w}$ pierwszej kolejności zdecydowano się na zastosowanie sprężyny o kształcie trapezowym, również charakteryzującej się dość równomiernym rozkładem naprężeń oraz zadowalającym ugięciem, które na dodatek nie powoduje przekroczenia jej maksymalnej wytrzymałości. Maksymalne naprężenie dla przyjętych jej wymiarów wyniosło $\sigma_{\max }=1440 \mathrm{MPa}$. 


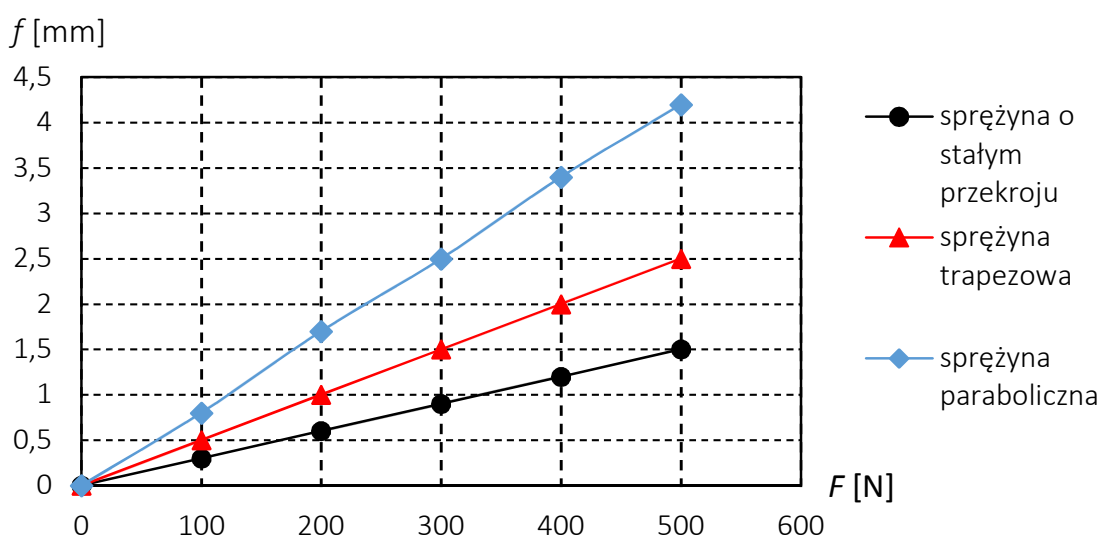

Rys. 5. Wartości ugięcia sprężyn o różnych kształtach w funkcji siły na nie wywieranej

Fig. 5. Values of deflection of different types of springs under the influence of force

\section{Podsumowanie}

Z opisanych rozważań, a także analiz przedstawionych w pracy [4] wynika, że dobór odpowiedniego typu oraz kształtu elementu sprężystego jest złożonym zadaniem. Uzyskanie kompromisu pomiędzy dostateczną sztywnością, wytrzymałością i sprężystością wymaga zastosowania bardziej skomplikowanej geometrii sprężyn płaskich lub niekiedy zestawów sprężyn, jak w przypadku sprężyn talerzowych opisywanych w artykule [4].

\section{Literatura}

[1] Cichosz P., Kuzinovski M.: Metody wykonywania fazek i gratowania krawędzi, Mechanik, 84 (2011) 674-681.

[2] Cichosz P.: Kasetka z ostrzem do samoczynnego wykonywania fazek, Patent PL 213332, Zgłoszono 14.09.2009, udzielono patentu 28.02.2013.

[3] Cichosz P., Kuzinovski M., Szymański W.: Możliwości kształtowania fazek i gratowania krawędzi narzędziami z ostrzami sprężystymi, Obróbka skrawaniem - współczesne problemy, Bogdan Kruszyński (red.), Łódź 2010.

[4] Cichosz P., Karolczak P., Kołodziej M., Kowalski M., Kuzinovski M., Skowronek H., Waszczuk K.: Elementy sprężyste fazowników samoczynnych, Mechanik, 89 (2016) 1424-1427.

[5] Matek W., Muhs D., Wittel H., Becker M.: Rolff/Matek Maschinenelemente, Frider Vieweg\&Sohn Verlagsgesellschaft GmbH, Braunschwig/Wiesbaden 1994. 


\section{ANALYSIS OF CUTTING FORCES DISTRIBUTION ON CUTTING EDGE OF ELASTIC CHAMFERING TOOL}

\section{S u m m a r y}

The article presents an analysis of an influence of the distribution of forces acting on the cutting edge in self-acting chamfering tools. The various types of flat springs for tensioning the blade were taken into consideration. The factors influencing the susceptibility characteristics of springs were presented. The guidelines for selection of the most favorable spring variants from the point of view of the most favorable chamfering tools working conditions were elaborated. Attention was drawn to the changes in the forces that act on the blade in the various phases of chamfering. The values of the cutting forces that can occur when shaping the edges of objects were determined. The analyzes also included active centrifugal forces and the change of forces due to the elastic deformation of the elements tensioning blade.

Keywords: edges bevelling, cutting process, bevelling tools, tools design

DOI: $10.7862 / \mathrm{rm} .2017 .31$

Otrzymano/received:12.07.2017

Zaakceptowano/accepted: 22.09.2017

Projekt finansowany przez Narodowe Centrum Badań i Rozwoju w ramach programu: INNOTECH III

\section{INNOWACYJNA
GOSPODARKA

